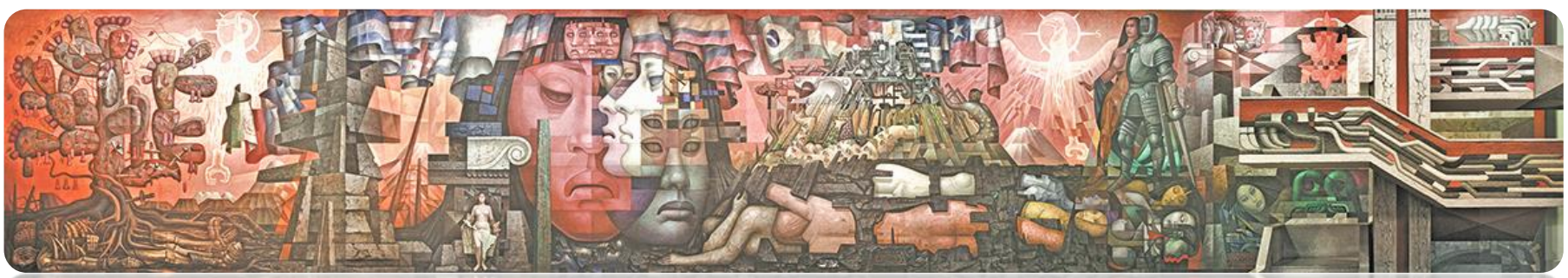

Rev. Hist., $N^{\circ} 28$, vol. 2, Julio-Diciembre 2021: 108-137

ISSN 0717-8832

https://doi.org/10.29393/RH28-29CSNM10029

\title{
Creación y supresión de la Real Audiencia de Concepción en Chile: el sistema de encomienda como clave en las relaciones entre gobernantes y encomenderos*
}
Creation and suppression of the Real Audiencia of Concepción in Chile: the system of encomienda as the key in the relationships between governors and encomenderos

\begin{abstract}
Neilyn Ferrada** Matthias Gloël***

\section{RESUMEN}

En este artículo planteamos el objetivo de esclarecer la equifinalidad causal que posee tanto la creación como la supresión de la Real Audiencia de Concepción. Esta investigación enfatiza en factores multicontextuales y en la influencia de la variación del tiempo para explicar ambos fenómenos. La utilización de método Process Tracing y el Corpus Real Audiencia de Concepción 1565-1573 de la Academia Chilena de la Historia fueron claves para el identificar el efecto de los periodos gubernativos desde Pedro de Valdivia hasta Melchor Bravo de Saravia en el fenómeno. Los resultados muestran una fuerte relación entre los intereses de los encomenderos y la supervivencia de los gobernadores chilenos en el poder.

Palabras Claves: Real Audiencia de Concepción, Encomenderos, Clientelismo, Sistema de Encomiendas, Process Tracing, Guerra de Arauco.

\footnotetext{
*El presente artículo es producto del proyecto de investigación Fondecyt de Iniciación 11190354.

** Universidad Católica de Temuco, Cientista Política. ORCID: https://orcid.org/0000-0002-3468-5541. Correo electrónico: neilynferrada@gmail.com

*** Universidad Católica de Temuco, Doctor en Historia. ORCID: https://orcid.org/0000-0002-9306-5801. Correo electrónico:mgloel@uct.cl
} 


\section{ABSTRACT}

In this article we propose the objective of clarifying the causal equifinality that both creation and suppression of the Real Audiencia of Concepción possess. This research emphasizes multi-contextual factors and the influence of time variation to explain both phenomena. The use of the Process Tracing method and the Corpus Real Audiencia de Concepción 1565 - 1573 of the Chilean Academy of History were key to identifying the effect of the government periods from Pedro de Valdivia to Melchor Bravo de Saravia on the phenomenon. The results show a strong relationship between the interests of the encomenderos and the survival of the Chilean governors in power.

Keywords: Real Audiencia of Concepción, Encomenderos, Clientelism, System of Encomiendas, Process Tracing, Arauco War.

Recibido: diciembre 2020

Aceptado: agosto 2021

\section{Introducción}

Entre los temas centrales que las investigaciones de la historia del siglo XVI han abordado, se encuentran las instituciones virreinale ${ }^{1}$, el derecho indígen ${ }^{2}$ y el sistema de encomiendas ${ }^{3}$. Este último fenómeno se puede considerar de primordial importancia para el periodo, ya que llegó a afectar la vida política, económica, social y cultural en las Indias. Los estudios sobre el sistema de encomienda han sido muy amplios. Primero, están los que tratan del trabajo indígena, posterior a la conquista. Segundo, los enfocados a las consecuencias en el orden social y político ${ }^{4}$ Y , finalmente, existe una gran cantidad de trabajos que se han encauzado en estudiar las expresiones del sistema de encomienda en la transformación cultural interesada en la posesión de tierras, mercedes y cargos públicos 5 .

\footnotetext{
${ }^{1}$ Rivero, Manuel. 2011. La edad de oro de los virreyes. El virreinato en la monarquía hispánica durante los siglos XVI y XVII, Madrid, Akal.; Cardim, Pedro. y Palos, Joan. 2012. El mundo de los virreyes en las monarquías de España y Portugal. Madrid, Iberoamericana.

2 Góngora, Mario. 1970. Encomenderos y estancieros, Santiago, Universitaria.

${ }^{3}$ Garriga, Carlos. 2006. "Sobre el gobierno de la justicia en Indias (siglos XVI-XVII)", en Revista de Historia del Derecho, N 34, Argentina, pp. 67-160; Hormaeche, Lisandro. 2010. "El sistema de la encomienda como aparato de control de la mano de obra indígena y de aculturación en el espacio Hispanoamericano (Siglos XVI y XVII)" en Cátedras Bolivarianas, Universidad Popular Madres de Plaza de Mayo, pp. 1-17.

${ }^{4}$ Dougnac, Antonio. 2004. "Las Audiencias Indianas y su trasplante desde la metrópoli" en Feliciano Barrios. EI gobierno de un mundo, Cuenca, Universidad de Castilla-La Mancha y de la Fundación Rafael del Pino, pp. 539-586; Cuervo, Benedicto. 2016. "La conquista y colonización de América", en Revista Historia Digital, 2 28, Madrid, pp. 103-149.

${ }^{5}$ Feliú, Guillermo. 1941. Las Encomiendas según Tasas y Ordenanzas, Buenos Aires, Facultad de Filosofía y Letras. Publicaciones del Instituto de Investigaciones Históricas; Sagredo, Rafael. 2014. Historia mínima de Chile, Madrid y México D.F, Turner y El Colegio de México; Salinero, Gregorio. 2015. "Rebeliones coloniales y gobierno de las Indias en la segunda mitad del siglo XVI” en Historia Mexicana, N³, Ciudad de México, pp. 895-936; Escudero, Alfredo.
} 
Así como se ha explicado un inmenso séquito de temáticas a través del sistema de encomienda, la Real Audiencia de Concepción, una de las experiencias institucionales más importantes del siglo XVI de Chile, ha sido poco examinada considerando el sistema de encomienda como un factor explicativo para su creación, su funcionamiento y su pronta supresión. La Real Audiencia de Concepción, al igual que otras audiencias coloniales, contó con atribuciones superiores a las audiencias peninsulares de Valladolid y de Granada $^{6}$. Sin embargo, al momento de estudiar su corto lapso de vida, se evidencia que se han escrito distintas teorías a la hora de explicar la creación y supresión de la Audiencia. Se detecta una falta de consenso acerca de cómo las distintas variables se afectaron mutuamente. Por ende, pensamos que incluir como factor explicativo al sistema de encomiendas en el análisis puede resultar en la posibilidad de generar una teoría historiográfica más consistente y coherente.

Los estudios sobre la Real Audiencia de Concepción y el interés por esclarecer los sucesos históricos respecto a su creación y supresión es un nicho en la historiografía chilena. De las muchas obras que tratan de las audiencias indianas en general ${ }^{7}$, la Audiencia de Concepción es la menos estudiada, y existe una necesidad de actualizar la discusión. Creemos necesario que se considere la coherencia continua entre las variables y entre ambos eventos en el tiempo, de manera que se incluya una visión de perspectiva y no de forma estática.

Los trabajos más representativos de la línea de investigación sobre la creación de la primera Audiencia de Chile han utilizado enfoques muy diferentes, pero técnicas y métodos homogéneos para llegar a sus conclusiones. Mazzei de Grazia ${ }^{8}$ identifica diversos factores y objetivos para la creación de la audiencia a través de cartas y documentos oficiales desde Concepción, Santiago y Perú, explicando que "las audiencias aparecieron como una solución apropiada para todo tipo de problemas" ${ }^{9}$. Desde Concepción, Rodrigo Vega Sarmiento expresó "V.M. no puede tener hacienda en este reino, si no es habiendo Audiencia, porque acá los gobernadores son absolutos y no quieren contradicción en nada, ni consultan ni tratan, sino mandan, y todo es su particular interese" ${ }^{10}$, era indispensable "que hubiera audiencia, en

2016. El ocaso de los conquistadores: los intereses y las limitaciones materiales durante la rebelión de los encomenderos (1544 - 1548), Pontificia Universidad Católica del Perú, Tesis para optar al grado de Licenciado en Historia.

${ }^{6}$ Miguel y Alonso, Carlos de. 1959. "Las audiencias en los reinos y señoríos de las Indias" en Cuadernos Hispanoamericanos, №116-117, Madrid, pp. 195.

7 Reig Satorres, José. 1972. "Las Audiencias Indianas: su origen y caracteres" en Reig Satorres, José. Reales Audiencias. Quito- Guayaquil, Anuario Histórico Jurídico Ecuatoriano, pp. 525-614; García, Alfonso. 1975. "Las audiencias de Indias, su origen y caracteres", en Memoria del Segundo Congreso Venezolano de Historia, Caracas, Academia Nacional de la Historia, pp. 359-432; Barrios, Feliciano. 2004. El gobierno de un mundo, Cuenca, Ediciones de la Universidad de Castilla-La Mancha.

8 Mazzei de Grazia., Leonardo. 1989. “Fundación y supresión de la audiencia de Chile: Concepción 1567-1575”, en Revista de Indias, $\mathrm{N}^{\circ} 49$, Madrid, pp. 28- 89.

9 Ídem., p.28.

10 "Carta de Rodrigo de Vega al Rey sobre varias materias de gobierno y hacienda. 12 de octubre de 1562", en Medina, José Toribio. 1901. Colección de Documentos Inéditos Para la Historia de Chile (en adelante CDIHCh), Tomo 
resguardo de las rentas reales porque los gobernadores manejan estos fondos a su voluntad, sin el respeto debido" ${ }^{11}$. Desde el Cabildo de Santiago, se "pidió una Audiencia como solución frente al mal gobierno de Francisco Villagra, para que hiciera imperar la paz y la justicia y no se sintieran agraviados los súbditos"12. Por último, en Perú

"El licenciado Monzón, fiscal de la Audiencia de los Reyes, escribió al Consejo de Indias, manifestando que, si no se ponía Audiencia en Chile, se corría el riesgo de que sus vecinos lo abandonaran a causa de los perjuicios que habían recibido, refiriéndose a los despojos de indios y de tierras que había hecho Francisco de Villagra a personas que fueron beneficiadas por García Hurtado de Mendoza"13.

También en Perú, el licenciado García de Castro, presidente de la Audiencia de Lima y gobernador de Perú solicitó una Audiencia para Chile. La carta dirigida al Rey con fecha 6 de marzo de 1565, expresó que una de las razones que más justificaban su fundación era la de "evitar las crueldades que habían hecho y continuaban haciendo los españoles a los indígenas, sin que los gobernadores pusieran el empeño adecuado para impedir estos abusos" ${ }^{\prime 14}$.

Por su parte, Barrientos ${ }^{15}$ explica a través de dos cartas los conflictos existentes en Chile. Desde Perú, los ministros del tribunal de Lima y los vecinos en contra del gobierno de Francisco y Pedro de Villagra manifestaron sus quejas respecto al manejo de la guerra con los nativos. Por otro lado, el Cabildo de Santiago escribió al rey el 3 de diciembre de 1563, expresando que "entendemos que los naturales, siendo, como son, belicosos, han entendido el temor que a los naturales tienen los españoles y el gobernador, no tan obedecido como sería menester, por donde deseamos Vuestra Majestad fuese servida de enviar Audiencia Real"16.

Unos años más tarde, el estudio de Eduardo Martiné ${ }^{17}$ aseguró que la creación de la Real Audiencia de Concepción fue una consecuencia de las consecutivas sublevaciones indígenas que, en una última instancia, le habían costado la vida a Pedro de Valdivia en diciembre de 1553. De ahí en adelante se implementaron gobiernos inestables por las rivalidades en que se enfrascaron diversos bancos en disputa, sin rigor para dirigir un territorio inestable, cruzado por la violencia y la falta de justicia. Esta identificación de factores responde, a diferencia del

XXIX. Desde el viaje de Magallanes hasta la batalla de Maipo: 1518-1818, colectados y publicados por J. T. Medina, Santiago, Imprenta Ercilla, p. 157.

${ }^{11}$ Mazzei de Grazia. 1989. “Fundación y supresión”, p. 29.

12 Ídem.

13 Ibídem, p. 30.

14 "Carta del Licenciado Castro al Rey. 06 de marzo de 1565", en Levillier, Roberto. 1921. Gobernantes del Perú" Cartas y Papeles, siglo XVI, Madrid Sucesores de Rivadeneyra, pp. 62-63.

${ }^{15}$ Barrientos, Javier. 1992-1993. “La Real Audiencia de Concepción (1565-1575)”, en Revista de Estudios HistóricoJurídicos, Nº 15, Valparaíso, pp. 131-178.

16 Ibídem, p. 133.

17 Martiné, Eduardo. 1997. “La Audiencia de Concepción en Chile (1565 - 1573) un caso de Audiencia con expresas funciones de gobierno", en Anuario de historia del derecho español, Nㅜ67, Madrid, pp. 1379-1398. 
texto de Barrientos, a la consideración innecesaria de examinar cartas de Perú, argumentando que los factores residen en los antecedentes chilenos y en los intereses de los gobernantes chilenos.

Estas discusiones y diferencias entre estas propuestas historiográficas son tema central en el prólogo del corpus Real Audiencia de Concepción 1565-1573, realizado por el historiador Javier González Echenique ${ }^{18}$, el cual asegura que no se puede conocer con certeza el proceso que condujo al establecimiento de la Audiencia. Sin embargo, no se pueden dejar de considerar como relevantes las quejas al gobierno de Villagra y el Ilamado de una Audiencia en la que resida el orden y la justicia. Específicamente, el autor asevera que las quejas giraban en torno al maltrato hacia los indígenas y al desorden para manejar la Hacienda Real, la cual era imprescindible para atender las múltiples necesidades de un reino en guerra.

Sobre el funcionamiento de la Audiencia de Concepción solamente se pueden hacer afirmaciones más bien generales. En 1563 las Ordenanzas Nuevas de Audiencias sustituyeron las antiguas que databan de los años 1528-1530. Las ordenanzas específicas para la Audiencia de Concepción del 18 de mayo de 1565 se basan en aquellas de $1563^{19}$. En ellas se definen las instalaciones, los principales cargos y los tipos de pleitos a ejecutar, tales como de gobierno, de hacienda o eclesiásticos.

De lo que apenas tenemos noticia, en cambio, es la actuación cotidiana concreta, es decir, los pleitos, con los que tuvo que lidiar la Audiencia. Lo anterior se debe, por una parte, a los desastres naturales. El 8 de febrero de 1570 un terremoto causó la destrucción de la ciudad y con ello la pérdida de mucha documentación ${ }^{20}$. Solo cinco años después, en 1575 , otro terremoto afectó gravemente la región. Si bien su epicentro fue en Valdivia, causó daños en todas las ciudades al sur del Bíobio ${ }^{21}$. A esto se suman los pocos pleitos que al parecer tuvo que atender la Audiencia a causa de la situación general, hecho expresado en una carta de los oidores Torres de Vera y Peralta al rey: "Nos ha parecido quel residir esta Real Audiencia aquí es de poco efecto, porque la gente y negocios son pocos a causa de estar los caminos de ordinario cerrados con la guerra y no osar los que tienen que pedir algo venir aquí" 22 . Así que, solamente tenemos noticias de algunos casos aislados como, por ejemplo, el pleito acerca de

\footnotetext{
${ }^{18}$ González, Javier. 1992. "Prólogo", en Academia Chilena de la Historia (en adelante AChH), La Real Audiencia de Concepción 1565-1573, Santiago, Editorial Universitaria, pp. 9-19.

19 “Ordenanzas para la Audiencia de Chile [Concepción], San Martín, 18, V, 1565, Archivo General de Indias. Aud. Chile. Leg. 170, cuad. I, f. 173-218 v" [en adelante AGI] en AChH, pp. 28-63.

${ }^{20}$ Steward, Daniel. 2019. "Historical tsunamis in the Penco Bay, as seen in the reconstructed runups from the city of Concepción, Chile (1570-1835)", en Revista de Historia de la Universidad de Concepción, N²6, vol.2 , Concepción, pp. 97-127, pp. 102-103

${ }^{21}$ Roa Palacios, Alfredo. 2015. Entre Ruinas Y Escombros: Los Terremotos en Chile Durante Los Siglos XVI al XIX, Valparaíso, Universidad de Valparaíso, p. 41.

22 "Carta del licenciado Juan Torres de Vera y del doctor Peralta al Rey sobre el gobierno, ejército y hacienda del reino", en Medina, José Toribio. 1956. CDIHCh, Segunda Serie, Tomo I, 1558-1572, Rodrigo de Quiroga - M. Bravo de Saravia, Santiago, Fondo Histórico y Bibliográfico J. T. Medina, p. 353.
} 
la venta de la estancia del valle de Quillota, efectuada por el obispo de Santiago, Rodrigo González, a su sobrino, negocio imputado por algunos caciques y el defensor de indios, caso llevado a la Audiencia de Concepción en $1572^{23}$.

Tras el breve repaso por las explicaciones del establecimiento de la Audiencia de Concepción, aún es necesario retomar uno de los planteamientos de este trabajo. ¿Qué factores determinan la supresión de la Real Audiencia de Concepción? La Supresión del tribunal fue decretada por Real Cédula el 20 de agosto de 1573. Los autores Góngora ${ }^{24}$, Barrientos ${ }^{25}$ y Martiné ${ }^{26}$ concuerdan en cuatro factores para explicar la supresión de la Audiencia de Concepción: primero, en una arena institucional se encuentran los desacuerdos entre el presidente y los oidores, junto con la corrupción del presidente. En la arena contextual hay dos factores, la presencia de la guerra para gobernar, junto a la inutilidad de la Audiencia.

Barrientos se inserta en el debate de la separación de poderes en la Audiencia afirmando que presidente y oidores no mantenían acuerdos en la forma de legislar. Ambas fuerzas políticas no encontraron acuerdos ni intereses para establecer un punto intermedio y no existía certeza de a quién le pertenecía más el reino. Sin embargo, no incluye en su discusión bajo qué factores la separación de poderes y las rencillas entre ministros se iniciaron, o cómo afectaron en el alcance institucional y su posterior supresión. El segundo problema de la arena institucional trataba de la corrupción del presidente. Esto constituía una acusación real y se puede agregar en este contexto que las actitudes ilegales dentro de las propias instituciones representativas de justicia eran más comunes de lo que se pensaba, ya que, por ejemplo, "Ios miembros de la Audiencia de Nueva España fueron destituidos, inculpados de haber usurpado tierras a los indios para sí y haberlos hecho trabajar en sus casas y heredades" ${ }^{27}$. Por ejemplo, el gobernador le dio de forma irregular a su propio hijo la encomienda de Maquegua, hecho que todavía en 1582 fue reprochado por parte del Consejo de Indias ${ }^{28}$.

En cuanto a la Audiencia de Concepción, "la residencia de Melchor Bravo de Saravia, tomada en 1575, estaba repleta de acusaciones de corrupción" ${ }^{29}$. Los autores afirman que,

\footnotetext{
${ }^{23}$ Venegas Espinosa, Fernando. 2011. "Segunda parte: Historia”, en Venegas Espinoza, Fernando, Ávalos, Hernán y Sauniers, Andrea (eds.). Arqueología e historia del curso medio e inferior del río Aconcagua. Desde los primeros alfareros hasta el arribo de los españoles (300aC-1600dC), Valparaíso, Pontificia Universidad Católica de Valparaíso, pp. $187-188$

${ }^{24}$ Góngora, Mario. 1951. El estado en el derecho indiano. Santiago, Universidad de Chile Instituto de Investigaciones Histórico-Culturales.

25 Barrientos. 1992-1993, "La Real Audiencia".

${ }_{26}$ Martiné. 1997, "La Audiencia de Concepción".

27 Góngora. 1951, El estado, p.61.

28 Zavala Cepeda, José Manuel., Medianero Soto, Francisco. y Zeballos San Miguel, Mirentxu. 2020. “Maquegua (Maquewe) y sus habitantes en la Araucanía del siglo XVI: geopolítica y economía aurífera en los términos de la Ciudad Imperial de Chile", en Memoria Americana. Cuadernos de Etnohistoria, №28, Buenos Aires,pp. 117-138, p. 125.

${ }^{29}$ Góngora. 1951, El estado, p.62.
} 
tras las graves acusaciones realizadas por el fiscal Navia, "Bravo de Saravia estaba acusado por el fiscal de malversación de fondos de la Corona: mantenía un secretario particular con el que hacía los repartimientos de indios cobrando suculentos derechos a las partes en provecho propio" ${ }^{\prime 30}$. Cabe señalar que ya al final de su tiempo como oidor de la Audiencia de Lima había enfrentado acusaciones similares, aunque finalmente no fue condenado ${ }^{31}$. Tampoco se considera que las arbitrariedades del presidente Saravia fueron consecutivas y advertidas, desde fechas tempranas, por los oidores, el fiscal Navia y el licenciado Calderón. Este último explica en la carta del 13 de noviembre de 1575 enviada al virrey del Perú lo sucedido en la residencia de la Real Audiencia: "se presentaron entre cincuenta y sesenta demandas en contra del presidente y oidores" 32 . De hecho, de forma exclusiva a Bravo de Saravia se le formularon más de 130 cargos, "en los cuales y en cada uno dellos el dicho juez absolvió al dicho doctor Saravia confirmamos la dicha sentencia por no probados (...) y absolvemos y damos por libre y quito al dicho doctor Saravia de los dichos cargos y de cada uno dellos" ${ }^{33}$. Se declararon diferentes delitos corruptivos del presidente, sin embargo, los trabajos expuestos en el párrafo anterior contemplan una dimensión susceptible a cambios institucionales, por ejemplo, la remoción del presidente de la audiencia o de los oidores. Desde 1569 fueron enviadas las primeras cartas al rey para solicitar la supresión de la audiencia, señalándose la necesidad de un nuevo gobernador y la sustitución de Saravia. Cabe recalcar que la presencia de Saravia como presidente no era imprescindible, ya que, como ilustra Mayorga ${ }^{34}$ para el caso de la gobernación de la Audiencia de Santa Fe, se pudo desarrollar sin la presencia de un presidente y con constantes sustituciones de sus oidores hasta lograr estabilizarse.

En concreto, los factores de la arena institucional no son causalidades suficientes por sí solas para fracturar la Audiencia, ya que la remoción de sus miembros siempre pudo ser una opción para finalizar las disconformidades y discrepancias entre oidores y presidente o las pugnas sobre corrupción informadas. Cabe recalcar que a través de esta argumentación no se contradicen los argumentos de Barrientos, Góngora y Martiné, sino que se evidencia la necesidad de identificar y concretar por qué nacen estos conflictos. ¿Por qué oidores y

\footnotetext{
30 Martiné. 1997, "La Audiencia de Concepción”, p.1389.

${ }^{31}$ Angeli, Sergio. 2004. "'No a habido causa de gobierno ni justicia que yo haya contradicho': cargos y descargos del doctor Bravo de Saravia ante la visita a la Audiencia de Lima (1561-1563)" en Revista de Historia del Derecho. Sección Investigaciones, $\mathrm{N}^{\circ}$ 47, Buenos Aires, pp. 13-31.

32 "Carta del licenciado M. Calderón al virrey del Perú sobre la residencia de la Real Audiencia, el refuerzo que trae Losada y parecer de trasladar parte de la población indígena de Chiloé a La Serena. 13 de noviembre de 1575", en Medina, José Toribio. 1957. CDIHCh, Segunda Serie, Tomo II, 1573-1580, M. Bravo de Saravia - Rodrigo de Quiroga, Santiago, Fondo Histórico y Bibliográfico J. T. Medina, p. 201.

33 "Ejecutoria del Consejo de Indias sobre la residencia que tomó el licenciado Calderón al doctor Bravo de Saravia, presidente que fue de la Audiencia de Chile, de 10 de marzo de 1582", en Medina, José Toribio. 1957. CDIHCh, p. 138.

${ }^{34}$ Mayorga, Fernando. 2013. Real Audiencia de Santafé en los siglos XVI - XVII. Historias, visitas, quejas y castigos del primer tribunal con sede en la ciudad. Bogotá, Secretaría General Alcaldía Mayor de Bogotá D.C. p. 536.
} 
presidente hicieron insostenible su relación institucional? ¿A partir de qué factores se llegaron a desarrollar estos problemas?

Respecto a la arena contextual, se debe considerar que la guerra acumulaba bastantes años y la Audiencia era precisamente la encargada de terminarla. En la primera batalla, las fuerzas de Saravia fueron derrotadas y el ambiente junto con el apoyo de los españoles se limitó firmemente. "La vuestra Real Audiencia y tuvo y gobernó un año este reino en toda paz y quietud sin perder una almena, hasta que vino el vuestro gobernador presidente doctor Bravo de Saravia y como la experiencia no le ayudaba quiso hacer en un año lo que los vuestros gobernadores no habían podido hacer en diez y seis y así juntó campo de doscientos hombres (...) y destruir el reino en una hora," 35 expresó el capitán Lorenzo Bernal de Mercado.

En este aspecto, fueron diversas las escrituras que solicitaban suprimir la Audiencia precisamente por encontrarse en un contexto de guerra. Por ejemplo, contamos con las cartas del Fiscal Navia de $1569^{36}, 1570^{37}$ y $1571^{38}$, las cuales hacen referencia a la necesidad imperante de resolver la guerra por encima de otras materias del tribunal. A esta discusión se suman las cartas del oidor Torres de Vera del 20 de febrero de $1571^{39}$ y el argumento de Diego Martínez de Peralta ${ }^{40}$ pidiendo la supresión de la audiencia y la redestinación de esos fondos para hacer frente a la guerra.

De este análisis se desprende el segundo factor de la arena contextual, la inutilidad de la Audiencia. En este marco, Martiné realiza el análisis sobre los efectos de la Audiencia considerando la falta de habitantes, la inequidad de los soldados con los nativos y la inutilidad de la Audiencia de Concepción en otras materias en medio del conflicto ${ }^{41}$. Asimismo, Barrientos profundiza en los impactos de territorio aledaño al conflicto indígena, entre ellos, mayor probabilidad de ser atacada, menor dedicación de tiempo a las labores de justicia, débiles herramientas para acudir a la resolución de conflictos civiles, altos gastos y menos presupuesto para otras materias igual o menos importantes que la guerra ${ }^{42}$. En este sentido, los autores afirman que la inutilidad del tribunal es un factor que definió su supresión, el cual

\footnotetext{
35 "Carta de Lorenzo Bernal de Mercado al Rey en que hace críticas al gobierno de Bravo de Saravia y pide socorro para la continuación de la guerra. 31 de mayo de 1569", en Medina, José Toribio. 1956. CDIHCh, p. 223.

36 “Carta, Concepción, 28, V, 1569, del licenciado Navia al Rey (AGI. Aud. Chile. Leg. 8, f. 1 a 10)", en AChH. 1992. Real Audiencia, pp. 250-264.

37“Carta, Concepción, 4, I, 1570, del licenciado Juan Navia al Rey (AGI. Aud. Chile. Leg. 8, f. 1-9)”, en Ídem, pp. 267276.

38 "Carta del licenciado Navia al Rey 27 de febrero de 1571 en que formula críticas a los procederes de la Audiencia (Archivo de Indias, 77-4-45. Manuscritos, t. 86, doc. 1129, pp. 182-200)", en Ídem, pp. 284-290.

39 "Carta del licenciado Juan Torres de Vera a S.M. 20 de febrero de 1571 informando de las consecuencias del desastre de Mareguano y estado de guerra (Archivo de Indias, 77-4-35. Manuscritos, t. 86, doc.1125, pp. 153-157)", en Ídem, pp. 276-278.

40 “Carta, Chuapa, 5, IX, 1568, del doctor Peralta al Rey (AGI. Aud. Chile. Leg. 8, f. 1)”, en Ídem, p. 245.

${ }^{41}$ Martiné. 1997, "La Audiencia de Concepción".

42 Barrientos. 1992-1993, "La Real Audiencia"
} 
es consecuencia del contexto de guerra. No obstante, estas teorías son controversiales, puesto que después de unos cuantos años de suprimida la Audiencia y aunque continuaba el conflicto con los nativos, nuevamente se solicitó a la Corona reconstituir la Audiencia en Chile. El 25 de agosto de 1583, Cristóbal Luis, mercader y secretario de gobernación, le escribió al rey señalando la conveniencia de que "provea audiencia que asista en esta ciudad de Santiago, que es el pueblo más barato de mantenimientos de este reino y cabeza de gobernación" ${ }^{43}$.

De esta manera, tanto la creación como la supresión de la Audiencia poseen inconexiones y falta de consenso, lo cual intenta resolver este trabajo a partir del análisis del sistema de encomiendas. ¿Qué factores determinaron la formulación y supresión de la Real Audiencia en Chile? ¿Cuáles son las aspiraciones de la Corona entre estos dos diferentes acontecimientos? ¿Qué sucesos marcaron las relaciones políticas en ambos eventos históricos? El objetivo de esta investigación es lograr aproximarse a las respuestasa a estas interrogantes a partir de la generación de un mecanismo causal sustentado en la recolección de documentos oficiales y la utilización de Process Tracing. Para ello, esta investigación tiene la siguiente estructura: primero, se desarrolla un recorrido por las principales explicaciones para considerar un mecanismo causal en base al sistema de encomienda. Luego, se explica la metodología de análisis para comprender la multiplicidad del fenómeno, la forma en que se construye el mecanismo causal y la debida justificación. Posteriormente, se expone la profundidad de los resultados y los argumentos secuenciales que explica. Por último, se desarrollan las conclusiones con especial énfasis en la continuidad de este trabajo.

\section{La relevancia del sistema de encomienda}

El sistema de encomiendas tuvo diferentes impactos y, por ello, diversas conceptualizaciones. A juicio de Lisandro D. Hormaeche ${ }^{44}$, el sistema de encomienda se sustentó en una relación entre dominadores y dominados con la sociedad indígena, fue un aparato organizador de la mano de obra nativa, produjo cambios en la distribución de la población y trajo consigo una doble finalidad: obtener riquezas e integrar al indígena a la cultura española por medio de la evangelización. Esta institución, que se insertó política, social y culturalmente en la sociedad del siglo XVI de Chile, no sólo fue una herramienta utilizada por los encomenderos para aumentar la apropiación de la mano de obra indígena, sino también fue el centro de la economía y la explotación aurífera desde la llegada de los españoles y fue "una institución que se convirtió en una realidad totalizadora para las comunidades indígenas" ${ }^{45}$. Con frecuencia

\footnotetext{
43 "Carta de Cristóbal Luis a Su Majestad dando noticias del estado del reino. 25 de agosto de 1583", en Medina, José Toribio. 1959. CDIHCh, Segunda Serie, Tomo III, 1577-1589, Martín Ruiz de Gamboa - Alonso de Sotomayor, Santiago, Fondo Histórico y Bibliográfico J.T. Medina, p. 171.

${ }^{44}$ Hormaeche. 2010, "El sistema de la encomienda", p. 1.

45 Contreras, Hugo. 2009. Encomienda y Servicio Personal entre las comunidades indígenas de Chile central, 15411580. Universidad de Chile, Tesis para optar al grado de Doctor en Historia, p.11.
} 
fue "utilizado por el Rey para premiar a aquellos que exponían su vida en el desempeño de servicios prestados en su persona" ${ }^{46}$. Precisamente, tras algunos años el repartimiento de encomiendas fue utilizado por los virreyes y gobernadores de cada reino, provocando el aumento de repartimientos solo en algunos, y el aumento de poder en ambas figuras. Contreras ${ }^{47}$ explica que en Chile el sistema de encomiendas provocó la obligación de que hombres, mujeres y niños proporcionaran mano de obra a los encomenderos por el tiempo que ellos estimaran pertinentes. Asimismo, el autor afirma que la encomienda reorganizó las comunidades indígenas, fragmentó grandes linajes, impulsó la cristianización y la imposición de normas sobre la sociedad prehispánica, tal como el idioma castellano. Igualmente, Cuervo menciona que la encomienda extendió la dominación española sobre el conjunto de la población y unificó un territorio que antes era ocupado por una serie de linajes, en los cuales no existía el concepto de unidad territorial, solo considerando las necesidades productivas de los encomenderos, lo cual posee coherencia con la fuerza militar utilizada como herramienta de conquista y la generación del conflicto guerrillero con los naturales, el cual causó "resistencia a la dominación española desde mediados del siglo XVI hasta mediados del siglo XVII"48.

Hasta el momento no hay claridad en cuanto a la relación entre el sistema de encomienda y la Audiencia de Concepción, y ello se debe a que los efectos de este sistema son diversos y dan frutos en distintas temporalidades. No obstante, los componentes de conflicto se ven evidenciados constantemente en cada gobierno, toman fuerza y repercuten así en la creación y supresión del tribunal. El sistema de encomienda, y la posesión de ella marcaron precedentes en los gobernadores desde la conquista de Chile. Frecuentemente se creaban quejas y escrituras respecto a los repartimientos, el manejo de la guerra y los marcados intereses contrapuestos de distintos grupos dominantes en el reino. ¿Por qué se generaron componentes de conflicto entre los diferentes gobernadores de Chile y los encomenderos? ¿Cómo se relacionan los conflictos sobre repartimientos de encomienda y el manejo de la guerra con la Real Audiencia de Concepción?

\section{El sistema de encomienda de servicio personal como mecanismo causal}

Los fenómenos y el contexto que envuelven a la Real Audiencia de Concepción señalan la necesidad de saldar el consenso entre las distintas variables explicativas. Por ende, se desea eliminar la equifinalidad entre variables y evaluar mecanismos causales hipotéticos. ProcessTracing (PT) es el método capaz de esclarecer tales teorías. Se puede considerar ya un método

\footnotetext{
46 Feliú, 1941. Las Encomiendas, p.35.

47 Contreras, 2009. Encomienda y Servicio Personal, p. 1.

48 Cuervo, 2016. "La conquista" p.125.
} 
probado para los procesos históricos, como evidencian, por ejemplo, los trabajos de Braudel ${ }^{49}$. PT relaciona eventos y procesos causales para realizar afirmaciones de qué variables son necesarias o suficientes para explicar un fenómeno. George y $\mathrm{McKeown}^{50}$ señalan que PT intenta descubrir los estímulos a los que los actores se atienden en el proceso de decisión y el comportamiento real que resulta de aquello. También, como proponen George y Bennett ${ }^{51}$, PT no es necesariamente atingente al individuo, sino también a procesos estructurales. Dada la causalidad compleja en la Real Audiencia de Concepción y la multiplicidad teórica para explicar eventos decisivos como su creación y su supresión, el método PT logra ser una herramienta útil para estudiar sus microfundamentos en base a una continua cadena de eventos secuenciales detallados y analizados, los cuales poseen una relación tanto inductiva como deductiva para dar resultado a la creación de una teoría. Para una explicación de la inferencia causal es necesario tener en consideración dos momentos, uno inductivo que comienza cuando existe una correlación, pero no hay claridad sobre su mecanismo causal. Por otro lado, el momento deductivo es en base a la evaluación de tales conexiones, es decir, "el inductivo se asocia con la generación de hipótesis y el deductivo con su testeo" ${ }^{52}$.

El sistema de encomienda es el pilar fundamental para desarrollar el mecanismo causal que sostiene esta teoría, pero no constituye su centro, ya que la clave está en sus orígenes y las consecuencias que desdoblan en los encomenderos, conquistadores y líderes gobernantes. Por ello, se extienden diferentes variables independientes esenciales para este trabajo. Dichas variables son las siguientes:

1. Repartimiento de encomiendas: entendido como la distribución de la mano de obra a través del servicio personal para trabajar las tierras y la explotación de minas. De ahí formulamos nuestra primera hipótesis de que los repartimientos de encomienda dan cabida al desarrollo de pleitos entre encomenderos y gobernantes de distintos periodos.

2. Intereses de los encomenderos: los encomenderos son los dueños del servicio personal, sus intereses se basan en la necesidad de enfocar todas sus fuerzas productivas a "la economía multiproductiva y tendiente a la autosustentación" ${ }^{\prime 53}$. Por ende, nuestra segunda hipótesis es que los intereses de los encomenderos y los objetivos de los gobernadores y de la Audiencia deben estar alineados para continuar en el poder.

\footnotetext{
${ }^{49}$ Fernand Braudel. 2019 [1949]. El Mediterráneo y el mundo mediterráneo en la época de Felipe II, México, Fondo de Cultura Económica.

${ }^{50}$ George, Alexander y McKeown Timothy. 1985. "Case Studies and Theories of Organizational Decision Making" en Robert Coulam y Richard Smith (eds.), Advances in Information Processing in Organizations, Greenwich CT, JAI Press, pp. $43-68$.

${ }^{51}$ George, Alexander. y Bennett Andrew. 2005. Case Studies and Theory Development in the Social Sciences. Cambridge, MIT Press.

52 Bril-Mascarenhas, Maillet \& Mayaux. 2017. “Process tracing. Inducción, deducción e inferencia causal”, en Revista de ciencia política, $\mathrm{N}^{\circ} 3$, Santiago, p. 664.

${ }^{53}$ Contreras.2009, Encomienda y Servicio Personal" p. 248.
} 
3. Clientelismo: en este estudio "las prácticas clientelares no se basan en la mera relación costo-beneficio donde cada parte pretende sólo maximizar sus ganancias, sino que también existe una dimensión simbólica, basada en lealtades, identificaciones e identidades grupales" $^{54}$. De ahí resulta otra hipótesis que el clientelismo y los favores políticos que provocaban los encomenderos eran una herramienta clave para que los gobernadores y la Audiencia de Concepción se mantuvieran en el poder.

4. Manejo de la guerra: entendido como las decisiones, estrategias y sucesos ocurridos según lo mandado por cada gobernador. La cuarta hipótesis, por tanto, consiste en que el manejo de la guerra es la base de los vecinos para reflejar quejas y reclamos constantemente para desacreditar a los gobernantes y a la Audiencia de Concepción.

\section{La Real Audiencia de Concepción y el sistema de encomienda}

Los argumentos para explicar las consecuencias del sistema de encomienda en la Real Audiencia de Chile se presentan en tres mecanismos causales. Primero, se argumenta cómo la rebelión peruana trajo transformaciones para los encomenderos en Chile, su relación con la Corona y como estos cambios empujan a la creación de la Audiencia de Concepción. En segundo lugar, se presenta el análisis sobre la relación entre el servicio personal, los gobernadores y los encomenderos, y se explica cómo el sistema de encomienda fue sujeto a una lógica sociopolítica clientelar que afectó la creación y supresión del tribunal. Por último, se profundiza en las relaciones políticas del presidente de la Audiencia de Concepción. Como resultado se obtiene la explicación a las diferentes variables claves que desencadenaron en la supresión del tribunal en Chile.

\section{A. Desarrollo institucional de la Corona}

La siguiente argumentación afirma que la Corona optó por diferentes estrategias para limitar el goce de encomiendas y regularizar el servicio indígena. Se potenció el control sobre los encomenderos como resultado del desarrollo institucional de la Corona generando la Real Audiencia de Chile

El dominico Bartolomé de Las Casas ${ }^{55}$, para condenar los hechos y la violencia contra los indígenas, impulsó la creación de las Leyes Nuevas (1542). Éstas trataban de "abolir el sistema de encomiendas, base social y económica de la población española en América" ${ }^{56}$. Tras la implementación, se generó la rebelión pizarrista, evidenciando "la fragilidad del gobierno de

\footnotetext{
${ }^{54}$ Drigo, Ana. 2005. La gran rebelión de Gonzalo Pizarro: liderazgo y legitimidad bajo su dirigencia en el Perú (15441548). Universidad de Buenos Aires, Tesis para optar al grado de Licenciatura en Ciencias Antropológicas, p. 6.

${ }_{55}$ Clayton, Lawrence. 2012. Bartolomé de Las Casas. A biography. Cambridge, Cambridge University Press; Castro, Daniel. 2007. Another face of empire. Bartolomé de Las Casas, indigenous rights and ecclesiastical imperialism, Durham, Duke University Press.

${ }^{56}$ Drigo. 2005, La gran rebellion, p. 15.
} 
las Indias, los abusos pertrechados contra los indios y la debilidad de la administración real" 57 . Pero, por sobre todo, se demostró que la encomienda era fundamental para los intereses de los conquistadores en América, por lo que "debe reconocerse que la rebelión de los encomenderos marcó una pauta de gobierno en el virreinato" ${ }^{58}$. De este modo, no tan sólo se debieron abolir partes de las Leyes Nuevas, sino también había que continuar gobernando a través del repartimiento de encomiendas.

En efecto, la Corona se vio en la necesidad de expandir su aparato administrativo, con la intención de abarcar mayor territorio en ciertos aspectos de las Leyes Nuevas, tales como la disminución del abuso en el servicio personal y la esclavitud de indígenas, la cual, en diversas ocasiones, era la base de las riquezas de los encomenderos. Salinero ${ }^{59}$ afirma que el deterioro de las Leyes Nuevas provocado por las rebeliones impulsó que la Corona mandara innumerables veces a que se liberen esclavos indios en las minas y luego, a todas las mujeres y niños de menos de catorce años que habían acabado prisioneros. De esta manera, surgió la necesidad de dar regulación al servicio personal y finalizar los crueles tratos a los naturales, aumentando la representación de la Corona a través de ordenanzas, la creación de nuevas audiencias y la multiplicidad de actores dentro de ellas. Por ejemplo, "las prescripciones de las Leyes Nuevas acrecentaron, de manera extraordinaria la notoriedad de los oidores" 60 , nutriendo cuantitativamente y cualitativamente el aparato institucional en las Indias.

Para profundizar en este punto, el trabajo de Antonio Dougnac ${ }^{61}$ resulta ser una herramienta fundamental para comparar la evolución y trascendencia de las ordenanzas para las Audiencias Indianas. El autor afirma que la actualización de las ordenanzas de 1563 se debe a la contribución y consideración de las Leyes Nuevas, con tal de resguardar el derecho indiano, en las robustecidas ordenanzas "habría cerca de doscientas cincuenta disposiciones nuevas en relación a las ordenanzas y legislación anterior" ${ }^{2}$, logrando ser aplicadas en la Audiencia de Concepción en 1565 por la real cédula dada en San Martín.

El tratado de Gobierno de Perú en 1567 de Juan de Matienzo, oidor de la Audiencia de Charcas, es el documento que revela la necesidad imperante de la Corona de colocar una Real Audiencia en Chile para aumentar su presencia en el territorio, hacer cumplir parte de las Leyes Nuevas y disminuir la probabilidad de nuevas rebeliones, el tratado señala que:

“La creación de tres nuevas audiencias en el Perú, incluyendo la de los Reyes, Charcas y Quito; una en Panamá y otra en Chile, fue propuesta por el Consejo de Indias al Rey, no tanto con el propósito de que los súbditos de lugares distantes tuvieron expedito acceso

\footnotetext{
57 Salinero.2015, "Rebeliones coloniales", p. 919.

58 Escudero.2016, El ocaso de los conquistadores p. 26.

${ }^{59}$ Salinero.2015. "Rebeliones coloniales", p. 917.

60 Salinero. 2015, "Rebeliones coloniales", p. 918.

61 Dougnac.2004, “Las Audiencias", pp. 539-586.

62 Ídem, p. 572.
} 
a la justicia, sino, principalmente, por motivos políticos, para asegurar la tranquilidad de la tierra: porque viendo que en todas partes hay audiencias, nadie se atreviera a levantarse, como lo han hecho hasta aquím ${ }^{63}$.

\section{B. Desarrollo de relaciones clientelares en Chile}

Durante 1548 Pedro de Valdivia fue nombrado por Pedro de la Gasca ${ }^{64}$ como gobernador y capitán general del reino de Chile, tras apoyar a la Corona para retomar el control sobre la rebelión en el Perú. Ana Laura Drigo ${ }^{65}$ explica que esta táctica fue crucial para los intereses de los conquistadores, pues la Corona podría asegurar en un entorno de legalidad las prestaciones y las ganancias acumuladas a quienes apoyaron el bando pacificador, más aún si las expediciones de Chile no estaban brindando un resultado exitoso. Por tanto, Pedro de Valdivia y su séquito evidencian una visión estratégicamente privatizadora al decidir brindar su colaboración guerrillera con la Gasca, puesto que "la corona no podía quitarles las encomiendas (...) y, a la vez, buscar su apoyo militar" ${ }^{\prime 6}$. Además, para ese entonces, la Corona ya había asumido la importancia y el poder de organización que tenían los encomenderos, y, por tanto, debió flexibilizar sus leyes para retomar el mando del Perú y disminuir la probabilidad de una nueva rebelión. Felipe Il debió abogar "por una vía intermedia, sin aceptar la perpetuidad de las encomiendas, pero sin abolirlas" 67 .

Posterior a tales recompensas, el gobierno de Valdivia se caracterizó por garantizar el flujo oportuno de sus riquezas junto a sus hombres de confianza. Resultó conveniente continuar con los descubrimientos, con el fin de mantener una cadena de fortuna estable en sus encomiendas. Sagredo ${ }^{68}$ explica que Valdivia poseía diversos motivos para ampliar la conquista, pero una de sus mayores preocupaciones era lidiar con la presión de quienes aún no lograban obtener una buena situación. Por ello, cuando consiguió fundar ciudades y hacer frente a la guerra mientras avanzaba al sur, las prácticas encomenderas se transformaron en técnicas consistentes para gobernar Chile. Por ello no es casualidad que Huneeus ${ }^{69}$ fundamente que Pedro de Valdivia, siendo gobernador, se encargó de extraer oro, repartir tierras, conceder encomiendas y obligar a los naturales a que trabajasen para los españoles. Directamente, Pedro de Valdivia marcó precedentes al colocar como prioridad a sus

\footnotetext{
63 Matienzo, Juan. 1967 [1567]. Gobierno del Perú, Lima, Institut Français d'Études Andines, p. 215.

${ }^{64}$ Merluzzi, M. 2010. La pacificazione del regno. Negoziazione e creazione del consenso in Perù, Roma,Viella, pp. 129-130.

65 Drigo.2005, La gran rebelión, p.114.

66 Salinero.2015, "Rebeliones coloniales" p. 922.

67 Diez T, Julián. 2011. "Los marañones y la polémica de la conquista: retórica e ideas políticas en la carta de Lope de Aguirre a Felipe II", en ALPHA, №33, Osorno, p. 203.

68 Sagredo. 2014, Historia mínima, pp. 39-49.

69 Huneeus P, Andrés. 1956. Historia de las polémicas de Indias en Chile durante el siglo XVI, 1536 - 1598, Santiago, Universidad de Chile, p. 149.
} 
seguidores y soldados más destacados a partir de la encomienda de servicio personal con tal de sostener compulsivamente la economía el reino, reafirmar su liderazgo y su capacidad política-militar. Este sistema trajo serias consecuencias a corto plazo debido a que los conquistadores comenzaron a forjar grupos de poder dirigidos a alcanzar la libertad respecto al dominio de las encomiendas y su respectivo repartimiento y/o adjudicación.

El estudio de Sagredo complementa esta teoría, ya que el autor asegura que la encomienda se transformó en un símbolo de riquezas para los conquistadores y un elemento diferenciador dentro de la sociedad. Es decir, ser conquistador y encomendero significaba acceder a cargos políticos designados por el propio Valdivia. La figura del gobernador implicaba poder, conexiones y fortuna. Por ello, no es coincidencia que el título de Pedro de Valdivia haya provocado envidias y rivalidades para sucederle luego de su muerte. Los lazos de redistribución respecto al sistema de servicio personal fueron el resultado de "una organización social que era dependiente de la figura del gobernador y a través de la cual fluía riqueza y las encomiendas" ${ }^{70}$.

Tras la muerte de Valdivia, durante unos cuatro años no hubo gobernación que recayera en una sola persona, lo cual sólo reforzó la inestabilidad en el Derecho Indiano, la expansión en las conquistas y el agotamiento guerrillero. Se trata de un "período categorizado por el aumento de localismo institucional y la privatización de las relaciones políticas entre los cabildos de las ciudades y los diferentes candidatos a suceder al gobernador en su puesto" ${ }^{71}$. Durante este periodo "los gobernadores encomiendan sin tener, a veces, poderes muy seguros para ello"72.

Cuando García Hurtado de Mendoza tomó la administración, había características decisivas que marcarían su gobierno, ligadas a las estrategias para poblar el territorio y de paso, dominar a los indígenas. El nuevo gobernador "estaba persuadido de que era posible reducirlos al vasallaje del rey de España por medio de la predicación religiosa y de un trato más benigno que el que ordinariamente les daban los conquistadores"73. A pesar de que Hurtado de Mendoza no era encomendero, se le permitía entregar y quitar repartimientos, con lo cual pagaba las hazañas y la dedicación en la guerra, es decir, con Hurtado de Mendoza se continuó utilizando la institución de la encomienda como medio para fortalecer distintos encomenderos en una cadena continua de recompensas.

\footnotetext{
${ }^{70}$ Escudero. 2016, El ocaso de los conquistadores, p. 72.

${ }^{71}$ Contreras, Hugo. 2017. "Indios de tierra adentro en Chile central. Las modalidades de la migración forzosa y el desarraigo (finales del siglo XVI y comienzos del XVII)" en Valenzuela, Jaime. América en diásporas. Esclavitudes y migraciones forzadas en Chile y otras regiones americanas (siglos XVI-XIX), Santiago, Instituto de Historia, Pontificia Universidad Católica de Chile, pp.161-196, p. 170.

72 Góngora. 1951, El estado p. 159.

73 Barros Arana, Diego. 2000 [1830-1907]. Historia General Tomo Il, Chile, Editorial Universitaria, p. 94.
} 
El trabajo de Lucía Invernizzi ${ }^{74}$ asegura que, Don García Hurtado de Mendoza había traído la restitución del orden, el rigor y eficacia en la organización y la práctica guerrera ${ }^{75}$. Sin embargo, los encomenderos criticaron incesantemente las decisiones del gobernador. Se establecieron cuestionables incriminaciones en los repartimientos de encomiendas de su gobernación, lo cual se tornó mucho más agudo tras la separación del mando ${ }^{76}$, ya que en el juicio de residencia ${ }^{77}$ del exgobernante se acumularon todo tipo de inculpaciones y quejas en contra de Hurtado de Mendoza. Esta instancia jurídica sería la oportunidad "en que iban a ser oídas todas las acusaciones que quisieran hacerles sus enemigos"78.

"Antes de mucho se formó un voluminoso expediente público (...) reprochábasele haber malgastado a su antojo la hacienda real, haber cometido todo género de injusticias en la distribución de los repartimientos, haber negociado en ventas y contratos, y recibiendo dinero por favorecer a algunos individuos, haber cometido actos de violencia contra muchas personas, haber despojado a otras de sus bienes, y no haber guardado en su conducta el recato y la gravedad correspondientes a su cargo" ${ }^{\prime 79}$.

El frenesí de los encomenderos contra Hurtado de Mendoza se debe al cambio que instauró el gobernador para efectuar los repartimientos de encomienda. En el gobierno de Pedro de Valdivia, los encomenderos obtenían diferentes tipos de recompensas por los trabajos entregados para la conquista del territorio. No obstante, cuando Hurtado de Mendoza asumió el poder, reformó y delimitó nuevos parámetros, favoreció a nuevos conquistadores y dejó de acumular riquezas a los antiguos encomenderos que hizo Pedro de Valdivia, dado que ya no participaban activamente en la conquista.

Luz María Méndez ${ }^{80}$, realiza un trabajo biográfico, el cual ordena los encomenderos que hizo Pedro de Valdivia y García Hurtado de Mendoza. En este texto se confirma que éste último mantuvo una fuerte inclinación para brindar repartimientos desvirtuando a los encomenderos que hizo Valdivia. En ese sentido, Javier Soto Becerra ${ }^{81}$ explica que, "el gobierno de García

\footnotetext{
74 Invernizzi, Lucía. 1989. “' ¿llustres hazañas? ¿Trabajos e infortunios?’ La Historia de Chile de Góngora Marmolejo”, en Revista Chilena de Literatura, N3, Santiago, pp. 7-22.

75 Ídem, p.14

${ }^{76}$ Errázuriz, Crescente. 1873. Los orígenes de la Iglesia chilena, 1540 - 1663, Santiago, Imprenta del Correo, p.141

77 Ídem.

78 Barros Arana. 2000 [1830-1907], Historia General, p.163.

79 Ídem, p. 303.

80 Méndez, Luz María. 2019. "El jurista Fernando de Santillán, el trabajo indígena y los encomenderos en el sur de Chile, especialmente Concepción y Arauco, 1550-1559" en Clímaco Hermosilla (ed.). Historia de Arauco: Garciadas Cañetinas, conferencias escogidas 2004-2018, Cañete, Sociedad Chilena de Historia y Geografía, Agrupación Cultural Artis, pp.21- 142.

81 Soto, Javier. 2018. Los encomenderos y las encomiendas en Concepción, 1550-1598, Universidad de Chile, Informe final del Seminario "Política, instituciones y grupos sociales (1700-1850)" para optar al grado de Licenciado en Historia.
} 
Hurtado de Mendoza (1557-1560) en la zona de Concepción hizo 26 modificaciones a las encomiendas que había entregado Pedro de Valdivia. Los beneficiarios fueron principalmente hombres que aún no habían recibido encomienda, 18 del total" ${ }^{82}$. Además, "Hurtado de Mendoza, hizo 13 encomiendas en viudas e hijos de antiguos encomenderos, apegándose en este aspecto a lo estipulado en la ley de sucesión" 83 .

De esta forma, se puede afirmar que el gobernador era receloso con los repartimientos y prontamente, estas características le traerían múltiples y persistentes reclamaciones de los líderes encomenderos insatisfechos de sus riquezas. Era sabido por el virreinato del Perú que en Chile "los soldados españoles que habían servido en la conquista o en las guerras civiles y que no habían alcanzado un repartimiento de indios que les 'diera que comer', no soñaban más que en revueltas o en nuevas expediciones que los enriqueciesen en poco tiempo" ${ }^{84}$. Por ello, no es coincidencia que el gobernador se haya antepuesto para asignar indios sólo a quienes las merecieran estrictamente. En consecuencia, surgieron empalagosos problemas sobre el dominio de ciertas encomiendas y se abrieron largos juicios en la Audiencia de Lima, dado que Hurtado de Mendoza había desacreditado méritos anteriores para dar a otros nuevos conquistadores.

Por ejemplo, existió una disputa de Juan Gómez de Almagro contra Antonio de Tarabajano por la posesión de un grupo de doce mujeres de las comunidades de Topocalma. En un principio había pertenecido al primero de ellos, pero, García Hurtado de Mendoza lo habría despojado para favorecer a Tarabajano ${ }^{85}$.

De esa forma también Barros Arana constata que los repartimientos de García Hurtado de Mendoza tenían una convicción personal que lastimaba los intereses de antiguos soldados, provocaron gran alteración en el mismo ejército, propias de las acusaciones e incriminaciones que dieron fruto en el juicio de residencia posterior a su destitución.

"Estos despojos arbitrarios, este favoritismo en el reparto de los beneficios de la conquista, habían de acarrear más tarde a don García las más tremendas acusaciones. Los damnificados y los ofendidos dijeron que el Gobernador había introducido en la administración la más espantosa inmoralidad, que daba mejores repartimientos al que le pagaba más dinero, que se guardaba el producto de los donativos y de las contribuciones de guerra, y que disponía del tesoro real y de los bienes de los particulares en provecho suyo y de sus parciales y allegados" 86

\footnotetext{
82 Ídem, p. 30.

83 Ídem, p.31

84 Ídem.

85 Contreras. 2009, Encomienda y Servicio Personal, p.288.

${ }^{86}$ Barros Arana. 2000 [1830-1907], Historia General, p. 194.
} 
En otro caso, existió una fuerte pugna de Juana Lezcano contra Julián de Bastida por el derecho a una encomienda de indios en Itata ${ }^{87}$. En profundidad, Pedro de Valdivia entregó repartimiento de indios a Giraldo Gil, esposo de Juana Lezcano en Itata en 1550. Tras su muerte, la viuda e hijos sucesores adquirieron tales herencias. Además, Giraldo Gil (hijo) recibió por parte de García Hurtado de Mendoza en 1557 una encomienda de indios del Licenciado de las Peñas que tenía junto a la de Diego Díaz. Tras la muerte de Giraldo Gil hijo, Juana Lezcano como madre y tutora inicia un juicio en contra de Bastidas por los derechos de encomienda de los indios de Itata el 27 de junio de $1560^{88}$, quien solicitaba cumplimiento de un repartimiento en la Audiencia de los Reyes dado por Diego Díaz según las posesiones entregadas por Pedro de Valdivia.

Para dar otro ejemplo, la Audiencia de Lima remitió al Consejo el largo proceso judicial de Luis de Toledo en contra de Julián de Bastidas que comenzó a inicios de 1560 y finalizó en agosto de $1561{ }^{89}$. Este caso trata sobre la posesión de los indios de Guachumavida encomendados en un repartimiento por Pedro de Valdivia. Luis de Toledo y Julián de Bastidas debieron presentarse a diferentes interrogatorios y probanza de méritos para discutir el título de encomienda ${ }^{90}$ que fue entregado por García de Mendoza a ambos.

Asimismo, el período de su sucesor Francisco de Villagra se vio envuelto en críticas por parte de los encomenderos, especialmente con la reactivación del conflicto indígena y la presencia de una epidemia de viruela que afectó a los españoles con el cierre de los trabajos en las minas. No obstante, el gobierno de Villagra se destacó por revelar la furia de los encomenderos en las minas del Marga- Marga, tras la creación de la ordenanza de $1561^{91}$ que trata de regular y dar protección al trabajo que ejercían los indígenas en las largas jornadas de mano de obra forzada. Posteriormente, los encomenderos nuevamente se vieron desafiados con las ordenanzas de Pedro de Villagra, el gobernador sucesor a la muerte de su primo Francisco. Pedro de Villagra, promulgó 12 reglamentos en apoyo a la Tasa de Santillán, la cual fijaba la extracción de oro. Esta última fue la primera regulación de la encomienda en Chile ${ }^{92}$. Como señala Contreras, "en Chile apenas se conocieron las Leyes Nuevas de 1542, (...) cuando

\footnotetext{
87 Méndez, Luz. 2019. “El jurista Fernando de Santillán”, p. 95.

88 Juana de Lezcano contra Julián de Bastidas, Archivo General de Indias, JUSTICIA, 403, N2, p. 1-5.

89 Luis de Toledo contra Julián de Bastidas, Archivo General de Indias, JUSTICIA, 403, N5, p.1-5.

90 "Información rendida en la ciudad de los Reyes por Julián de Bastidas en el pleito que trata con Luis de Toledo sobre indios y de la que constan sus méritos y servicios. 23 de febrero de 1560"; "Interrogatorio y título de una encomienda de indios presentados por Luis de Toledo en el pleito con Julián de Bastidas. 16 de febrero de 1560"; Probanza de los méritos y servicios de Luis de Toledo. 6 de febrero de 1560" en Medina, José Toribio. 1899. CDIHCh, Tomo XIX, desde el viaje de Magallanes hasta la batalla de Maipú, 1518-1818, colectados y publicados por J.T. Medina, Valdivia y sus compañeros. 1899. Santiago, Imprenta Elzeviriana, pp. 67-82, pp. 83-87, pp. 88-118.

${ }^{91}$ Feliú. 1941, Las Encomiendas, p. 104.

92 Contreras, Hugo. 2017b. Oro, tierras e indios. Encomienda de servicio personal y comunidades indígenas en Chile central, 1541-1580, Santiago, Universidad Academia Ediciones, p. 374.
} 
éstas eventualmente podrían haberse aplicado en el reino, fueron derogadas por la Corona y nunca se llegaron a implementar" ${ }^{\prime 3}$.

Para los encomenderos el servicio personal fue "un sistema que tendía a la autosustentación y, por lo tanto, dependía de la pluralidad de las funciones que los indios debían cumplir para llevar adelante dicho esquema productivo" ${ }^{\prime 4}$. Es por esto que las ataduras y barreras impuestas por Hurtado de Mendoza, Francisco y Pedro de Villagra, en oposición a los intereses económicos arraigados en los encomenderos, desataron un conflicto entre las disposiciones para defender el derecho indiano y la codicia infrenable de un grupo de poder consolidado a partir de las encomiendas. Los encomenderos jugaron "un gran papel en la vida económica de la colonia (...) donde inician su lucha contra todos aquellos que tiendan a perjudicar sus prácticas y su unión con aquellos que los favorecen" ${ }^{95}$. En el trabajo de Francis Goicovich se complementa esta apreciación, ya que el autor afirma que "la dimensión económica en que se fundaba la institución de la encomienda se superpuso al ideal evangelizador" ${ }^{\prime \prime 6} y$, por tanto, la encomienda sólo giraba y se relacionaba directamente con los intereses dentro del juego de poder que dominaban los encomenderos. En este sentido, se explica que la evangelización pertenecía a una de las tantas obligaciones que cada conquistador estaba deseoso de evadir, dado que ese rol estaba totalmente contrapuesto con el deseo de acrecentar sus riquezas.

De este apartado se identifica el papel imprescindible que jugó la Audiencia de Lima, para gestionar todo tipo de información que llegaba desde Chile para estratégicamente notificar a la Corona. Tan sólo de considerar las diversificadas cartas del oidor Monzón ${ }^{97}$ y específicamente, todas las cartas enviadas durante el $1565^{98}$ y $1566^{99}$ pertenecientes al

\footnotetext{
93 Contreras. 2009, Encomienda y Servicio Personal, p. 94.

94 Ídem, p. 221.

95 Feliú.1941, Las Encomiendas, p. 106.

${ }^{96}$ Goicovich, Francis. 2020. "Un reino con dos escenarios. La cuestión del trabajo y los derechos indígenas en la Gobernación de Chile en la etapa pre-jesuita: entre el nativo encomendado y el auca sublevado", en Revista Tiempo Histórico, №19, Santiago, p.27.

97 Barrientos, Javier. 1992-1993. "La Real Audiencia”, p. 133; “Capítulo de carta, Lima, 20, XI, 1564, del licenciado Monzón al Rey (AGI. Aud. Lima, Leg. 25, f. 1 a 4 v)" en AChH, p. 233.

98 "Fragmentos de carta del licenciado Castro sobre la partida de Jerónimo Costilla a la cabeza de los doscientos hombres en socorro de Chile y problemas de gobierno de este reino. Fecha en los Reyes. 6 de marzo de 1565"; Fragmento de carta del licenciado Castro acerca del socorro de doscientos veinte hombres enviados a Chile. Fechada en los Reyes. 26 de abril de 1565"; "Párrafo de carta del licenciado Castro a S. M. recomendando poner Audiencia en Chile. Fecha en los Reyes. 15 de junio de 1565"; "Párrafos de carta del licenciado Castro a S. M., dando cuenta de la vuelta de Costilla al Perú y de lo que hizo en Chile; pide Audiencia para esta gobernación. Fecha en Lima. 23 de septiembre de 1565"; "Fragmento de carta del licenciado Castro al Consejo de Indias sobre la designación de Rodrigo de Quiroga para gobernador de Chile, demanda de Pedro de Villagra y conveniencia de trasladar la Audiencia de Quito a Chile. Fecha en los Reyes. 25 de septiembre de 1565" en Medina, José Toribio. CDIHCh, pp. 30-33, pp. 34-35, p.36, pp. 46-49, pp. 50-51.

99 "Párrafos de carta del licenciado Castro a S. M. sobre el gobierno de Rodrigo de Quiroga y otros asuntos. 5 de junio de 1566" en Ídem, pp. 65-67.
} 
licenciado Castro, presidente de la misma Audiencia, se logran identificar los diferentes problemas que hacían necesario pronunciar la idea de una Audiencia para Chile. Tales afirmaciones, corroboran nuevamente todos los conflictos y urgencias que ocurrían consecutivamente en los gobiernos. En la práctica, la Audiencia de Lima logró evidenciar los escenarios y el contexto que mantuvieron Hurtado de Mendoza y los gobiernos de Francisco y Pedro de Villagra respecto al sistema de encomienda, sus repartimientos y respectivos méritos. Estos procedimientos demostraban alta concentración de poder y autonomía, lo cual precisamente, desbordaba aún más conflictos y la ausencia de institucionalidad virreinal.

\section{Consecuencias para la supresión de la Real Audiencia.}

En 1569, el presidente Melchor Bravo de Saravia salió derrotado en la batalla de Mareguano. Como consecuencia, se fundó una pésima visión hacia su persona y el gobernador perdió todo el prestigio por el cual había sido investido como presidente en la primera Audiencia de Chile. Su decisión en este conflicto lo condenó a ser percibido como un mal líder y un hombre poco prolijo para la guerra. Cabe señalar que, a pesar de ser letrado, Saravia contaba con experiencia militar, ya que participó en la supresión de la rebelión encabezada por Hernández Girón en el Perú en los años 1553-1554. Sin embargo, esa reputación ya no era suficiente para confiarle el reino según la opinión que expresaron los principales encomenderos de la época en Chile.

En la balanza de las expectativas encomenderas, la figura de Saravia no fue atractiva, la pérdida de esta batalla delimitaría la ayuda de los españoles en el futuro y lo llevó al cuestionamiento de muchos respecto a la creación de la Audiencia. Tras la fallida temporada de guerra de 1569 el Fiscal Navia fue de los primeros en reportar al rey los hechos y las decisiones de Saravia en la carta del 28 de mayo de 1569.

"Creo según el reino se perderá por falta de quien lo gobierne y haga las cosas de guerra, porque ya este cargo no tiene ventura (...) acometió una montaña tan áspera como digo con ciento y cuarenta hombres (...) lo cual hizo contra el parecer y voluntad de toda la más gente de experiencia de este reino, y contra toda buena orden de guerra según todos los antiguos de este reino cuentan, y perdió en esta jornada" ${ }^{100}$.

A estas críticas se suma la documentación recolectada por José Toribio Medina en la Colección de Documentos Inéditos para la Historia de Chile, donde es posible encontrar las quejas de Martín Ruiz de Gamboa ${ }^{101}$, del Cabildo de Concepción ${ }^{102}$, Lorenzo Bernal del

\footnotetext{
100 "Carta del licenciado Navia al Rey. 28 de mayo de 1569", en AChH. 1992. Real Audiencia, p. 251.

101 "Carta de Martín Ruiz de Gamboa a S.M. refiriéndose al socorro y a la guerra de Arauco y a su entrada a Chiloé. 24 de mayo de 1569", en Medina, José T. 1956. CDIHCh, p. 194.

102 "Carta del Cabildo de la Concepción al Rey dándole cuenta del desastre de Mareguano y el envío de socorro. 26 de mayo de 1569", en Ídem, p. 199.
} 
Mercado ${ }^{103}$, Rodrigo de Quiroga ${ }^{104}$, Fray Lope de la Fuente ${ }^{105}$, Fray Antonio de Carvajal ${ }^{106} \mathrm{y}$ Rodrigo de Vega Sarmiento ${ }^{107}$. La multiplicidad de quejas desacreditó al tribunal no solo dentro del reino de Chile, sino que éstas trascendieron al virreinato y fuera del continente. El virrey Toledo también envió cartas al rey en marzo y junio de 1573 opinando sobre la forma correcta de dirigir la guerra, en la primera aseveró que "el doctor Saravia entiendo que está muy viejo para aquello y aun para otro trabajo" ${ }^{108}$. Posteriormente fue incluso más drástico en su opinión sobre Saravia dando la idea de "proveer un presidente y gobernador y capitán general que supiese más de esto que de letras" ${ }^{109}$. Está claro que la batalla de Mareguano, junto a la pérdida de las ciudades de Cañete y el fuerte de Arauco, fueron elementos esenciales para desvirtuar la figura del presidente y conformar un gran obstáculo para gobernar sin una figura con legitimidad. No obstante, la guerra no es el único factor para pronunciar la ineficiencia de Saravia. El señor San Miguel en la visita de su diócesis en la Ciudad de Concepción señala como "inepto al gobernador Bravo de Saravia para las azarosas constancias que atravesaba el reino" ${ }^{\prime 110}$. Asimismo, San Miguel profundizaba en el desaprovechamiento del cargo debido a que no se tenía claro lo que había hecho y avanzado en hacer cumplir el derecho indiano ${ }^{111}$.

Bravo de Saravia, el gobernador y presidente de la Audiencia de Chile, enfocó todos sus esfuerzos por buscar acompañamiento en el conflicto con los nativos durante toda su gobernación. Llegó a solicitar ayuda respaldando todas las penurias que se decían de su gobernación a través de diversas solicitudes de recursos al rey, en base a relatos de duras penas, pobrezas en la hacienda y en la ardua tarea de capitán y militar de guerra (cartas de

\footnotetext{
103 "Carta de Lorenzo Bernal de Mercado al Rey en que hace críticas al gobierno de Bravo de Saravia y pide socorro para la continuación de la guerra. 31 de mayo de 1569", en Ídem, p. 222.

104 "Carta de Rodrigo de Quiroga a S. M. formulando críticas al sistema de guerra de Bravo de Saravia. 30 de junio de 1569", en Ídem, p. 227.

105 "Carta de fray Lope de la Fuente al Rey en que relata el suceso de Catiray y sus consecuencias, el descrédito del gobernador Bravo de Saravia y la conveniencia de que tome el mando Rodrigo de Quiroga. 1 de agosto de 1569", en Ídem, p. 232.

106 "Carta de fray Antonio de Carvajal al Rey refiriéndose a los desaciertos cometidos durante el gobierno de Saravia y de la Audiencia y sugiriendo que se nombre gobernador a García Hurtado de Mendoza. 12 de septiembre de 1569", en Ídem, p. 237.

107 "Carta del factor Rodrigo de Vega Sarmiento al Rey sobre las causas que han influido en la perdición del reino. 15 de junio de 1569", en Ídem, p. 225.

108 "Fragmento de carta de don Francisco Toledo, virrey del Perú, a S. M. 20 de marzo de 1573 opinando sobre las personas y forma en que dese ser dirigida la guerra de Arauco (Archivo de Indias, 70-1-29. Manuscritos, t. 230, doc. 5975, pp. 112-118)", en AChH. 1992. Real Audiencia, p.317.

109 “Capítulo de carta, La Plata, 3, VI, 1573, del virrey Toledo al Rey (AGI. Aud. Lima, Leg. 29)”, en Ídem, p. 318.

110 Errázuriz, Crescente. 1873. Los orígenes de la Iglesia chilena, p.247.

111 Ídem.
} 
mayo de $1567^{112}$, mayo de $1569^{113}$, diciembre de $1569^{114}$ y octubre de $\left.1571^{115}\right)$. Sin respuestas positivas, el gobernador buscó afianzar las relaciones políticas con distintos encomenderos provocando discrepancias con los oidores, utilizó sus poderes judiciales para hacer inválidas las regulaciones legales de la Audiencia, y así dar el favor a los encomenderos con tal de mantenerlos en una posición pacífica hacia su persona y gobierno. Saravia desaprobó cobranzas, multas, tributaciones y cualquier imposición de los oidores que pudiera generar una enemistad, ya que "las multas y las intenciones de establecer encomiendas de tributo, desataron las airadas protestas de los encomenderos. Pero el gobernador Bravo de Saravia, que necesitaba del concurso de los vecinos para sustentar la guerra, los calmó" ${ }^{116}$, convenciéndolos que "no serían con tanto rigor; y que, estando los indios tasados, se quitarían de visitas costosas, porque ya que las hubiese, no serían con tanto rigor; y que, estando los indios tasados, podían llevar los aprovechamientos sin conciencia" ${ }^{117}$. Con Saravia como decisor sobre la justicia y paz de Chile, se marcó la desobediencia respecto a las ordenanzas que moldeaban a la Audiencia, "limitaba la actuación de la audiencia a la competencia que le era propia" ${ }^{118}$. Estas decisiones fueron coyunturales para el futuro de la Audiencia, ya que respondieron a la manera en que conquistadores, encomenderos y gobernadores anteriores habían estructurado sus relaciones políticas, en torno al clientelismo y los favores políticos.

En este sentido, Feliú ${ }^{119}$ argumenta que cuando se trata de las encomiendas se establece una intensa relación entre autoridades y vecinos. Cada gobernador nuevo conlleva en el despojo de parte de los encomenderos, ya que éste viene acompañado del repartimiento de beneficios en cada círculo, siendo los desposeídos los nuevos enemigos del reino, procurando la caída del actual gobernante con insistencia escribiendo carta tras carta. Bajo estos términos, los gobernadores de Chile realizaban repartimientos de encomiendas de servicio personal a quienes les parecía y con la llegada de la Audiencia se ampliaron las atribuciones en el cargo de gobernador, extendiendo mayor poder y libertad para hacer y deshacer dentro de reino a favor de quien se encontraba al mando.

\footnotetext{
112 “Carta, Concepción, mayo de 1567, del doctor Bravo de Saravia al Rey (AGI. Aud. Lima, Leg. 92, f. 1 a 3)", en AChH. 1992. Real Audiencia, pp. 234-239.

113 “Carta, Concepción, 26, V, 1569, de Melchor Bravo de Saravia, el licenciado Egas Venegas, el licenciado Juan Torres de Vera y el doctor Peralta al Rey (AGI. Aud. Chile. Leg. 8, f. 1-1 v.-2)", en Ídem, pp. 247-250.

114 "Carta, Concepción, 24, XII, 1569, de Melchor Bravo de Saravia, el licenciado Egas Venegas y el doctor Peralta al Rey (AGI. Aud. Chile. Leg. 8, f. 1.1 v.)", en Ídem, pp. 265-267.

115 "Carta, Concepción, 28, X, 1571, de Melchor Bravo de Sarabia, Juan Torres y Vera y Diego Martinez de Peralta al Rey (AGI. Aud. Chile. Leg. 8, f. 1-1 v.)", en Ídem, pp. 308- 310.

116 Mazzei de Grazia. 1989, "Fundación y supresión”, p. 54.

${ }^{117}$ Góngora, Alonso. 2016[1575]. Historia de todas las cosas que han acaecido en el Reino de Chile y de los que lo han gobernado, Chile, Editorial Universitaria, p. 445.

${ }^{118}$ Barrientos.1992-1993, La Real Audiencia, p. 145.

119 Feliú. 1941, Las Encomiendas, p. 110.
} 
Fue así como Saravia organizó las relaciones del reino y con los encomenderos de forma beneficiosa para velar por su propio cargo. Resulta evidente que los intereses de los encomenderos debían estar dentro de las principales preocupaciones de los gobernadores, de lo contrario eran duramente desacreditados hasta ser destituidos. No es ninguna anomalía encontrar extractos que afirman la importancia de pagar a través de repartimiento de encomiendas a los conquistadores. Incluso si no se pagaba en encomienda a quienes lo pedían, los gobernadores eran duramente criticados. Por ejemplo, cuando muere la esposa de Francisco de Villagra, es el obispo quien pide al rey que se retribuya a su hijo los grandes servicios que dio su padre a la Corona dado que el gobernador Saravia ha decidido encomendar todo a su propio hijo; "el corazón del obispo protesta i clama repetidas veces (...), le recuerda [al rey] la triste situación del hijo [de Francisco de Villagra] i los grandes servicios prestados por el padre" 120 con el fin de lograr alcanzar repartimientos de encomiendas para quien lo solicitaba. Es decir, el sistema de encomiendas conformó una herramienta para entablar el contrapeso y el control en la figura de gobernador, ya que los encomenderos se transformaron en un grupo importante del sistema político y social. En el trabajo de Crescente Errázuriz, se evidencia a través de un extracto lo fundamental que es para la Audiencia complementar sus políticas y decisiones acorde a lo que determinen mejor los encomenderos:

“Pero, a pesar de todas las precauciones tomadas por la audiencia para no herir a los encomenderos, éstos no quedaron satisfechos. Querían evitar a todo trance la supresión del servicio personal; estaban resueltos a hacer con este objeto supremos esfuerzos; miraron el proyecto de la audiencia, por suave que fuera en la forma, como una verdadera amenaza a lo que llamaban sus derechos adquiridos, i comenzaron a manifestar claramente su descontento" 121

Los oidores Egas Venegas y Torres Vera en reiteradas ocasiones evidenciaron los comportamientos de los encomenderos con el presidente, y entre los diversos problemas se escribió sobre la organización de los vecinos entre sí para desviar los tributos de la real hacienda.

"Las cajas de este reino estaban muy adeudadas en grande suma de pesos de oro (...) no se envía relación entera de todo por estar tomadas las cuentas; a los oficiales reales que usaban los oficios en las ciudades (...) créese se seguirá a Vuestra Majestad de esto notable daño, porque habiéndose de repartir los tales oficios entre vecinos, o no tendrán las partes que se requiere para poderlos usar, o si acaso las tuvieren, no cobraran las debidas que a Vuestra Majestad se le deben por estar repartidas entre vecinos, y habiéndose andar los

\footnotetext{
120 Errázuriz. 1873, Los orígenes, p. 248.

121 Ídem, p. 250
} 
tales oficios siempre entre ellos, así se guardarán siempre las caras, y la cobranza de vuestro real hacienda vendrá en disminución" ${ }^{122}$.

A pesar de que Bravo de Saravia intentó corregir estos abusos y colocó corregidores en cada ciudad tal como lo mandaban las ordenanzas de 1563, "la designación de esos empleados dio lugar al favoritismo. Cada cual quería acomodar a sus parientes o allegados, y de allí nacieron quejas que aumentaban el descontento de los que creían que sus servicios no habían sido premiados como correspondía"123. En respuesta, los encomenderos proporcionaron duras quejas contra esta entidad, argumentando que sólo implicaría gastos, cuando la prioridad era la guerra. Según Mazzei de Grazia ${ }^{124}$, en Osorno se produjeron levantamientos en contra de los corregidores Antonio Martínez de la Cruz y Antonio de Lastur con la justificación que no actuaban en contra del rey, sino que en contra de quien los oprimía.

La corrupción del presidente es evidente, pero también es causa directa para explicar los desacuerdos que surgieron entre los oidores y el presidente de la Audiencia puesto que los objetivos que respaldaba su creación se encontraban inconclusos. Los oidores constantemente invalidaban las acciones del presidente y los repartimientos junto al favoritismo que impulsaba Saravia con algunos encomenderos fueron cancelados. Se dejaron congeladas e inhabilitadas diferentes materias, fortaleciendo así la mala opinión pública que tenía Saravia hasta suprimir el tribunal.

\section{Conclusiones}

Tal como fue señalado a lo largo de estas líneas, los estudios sobre la Real Audiencia de Concepción forman parte de una ya limitada producción. A la escasa existencia de archivos y fuentes disponibles sobre esta temática, se sumaron las diferentes líneas teóricas historiográficas para la producción científica que tornaron dificultoso la comprensión de este fenómeno. El presente trabajo ha logrado estructurar y conectar distintos procesos históricos para abordar la relevancia de la encomienda de servicio personal para explicar cómo y cuales características determinaron la creación y supresión de la Real Audiencia de Concepción como un mecanismo causal. De esta manera el aporte es doble: se exponen las teorías más representativas para contribuir con nuevos antecedentes al origen de las variables. Al mismo tiempo, se ha profundizado en los intereses y antecedentes que giran en torno al sistema de encomienda, los cuales revelan un característico clientelismo entre gobernadores, conquistadores y encomenderos.

\footnotetext{
122 “Carta, 20, XI, 1567, de los licenciados Egas Venegas y Juan de Torres al Rey (AGI. Aud. Chile. Leg. 8, f. 1-1 v. 3-3 v.)", en AChH. 1992. Real Audiencia, p. 243.

123 Barros Arana. 2000 [1884], Historia General, p. 324.

124 Mazzei de Grazia. 1989, “Fundación y supresión”, pp. 1379-1398.
} 
Las diferencias que aporta este estudio son amplias. Destaca el origen y las consecuencias de cada variable para poder dar cuenta de la unión de procesos importantes en las decisiones políticas de gobernantes, oidores y encomenderos. Se conformaron conexiones peculiares, como las relaciones clientelares fallidas y el contrapeso de la separación de poderes impuesta por los oidores. Estos factores no dejaron de causar otros efectos dentro de los procesos que llevaron a la supresión de la Real Audiencia de Concepción. Como ya se ha mencionado, las investigaciones ya realizadas no han considerado con la importancia necesaria el origen y las consecuencias del sistema de encomiendas en los eventos de la Real Audiencia de Concepción. Los estudiosos de este fenómeno se han dedicado a trabajar diferentes espacios temporales para dar cabida a los pleitos metodológicos para explicar la Audiencia, pero no han explorado ni continuado una línea causal multidinámica que pueda relacionar todas las variables explicativas existentes. Y precisamente, ese es el mayor aporte de este trabajo. La creación de la audiencia se genera en base a la expansión de la Corona para aumentar su presencia en territorio americano, la pugna por la ilegalidad de las encomiendas entre las Leyes Nuevas y la rebelión de los encomenderos que evidenció las debilidades del sistema político representativo del rey. En este marco es donde se observa una sociedad capaz de organización y liderazgo a cambio de mantener las encomiendas a su uso y parecer. Las disputas fueron pacificadas por la Corona, se instauraron las ordenanzas de 1563 y nuevas Audiencias, incluyendo una para Chile.

Este estudio ha evidenciado las características sociopolíticas de los encomenderos y gobernadores. Se revela una consistente relación clientelar en el gobierno de Pedro de Valdivia, los conquistadores y los encomenderos. Según lo argumentado anteriormente, el gobernador impuso un orden sistemático entre sus seguidores y más fieles soldados, proporcionando recompensas y encomiendas a cambio de acompañarlo en sus planes. El clientelismo sostuvo esta relación colocando a los gobernadores en la facultad de dar y quitar para validar su posición política, como medio de pago por el mérito entregado. Los posteriores gobiernos de García Hurtado de Mendoza, Francisco de Villagra y Pedro de Villagra colocaron ciertas normas para supervisar el trabajo indígena, evaluar la disminución de la población y manejar la guerra exitosamente en el caso de García Hurtado de Mendoza. De todas maneras, todos los gobernadores se enfrentaron a diferentes quejas y desacreditación hasta que fueran removidos. Con Rodrigo de Quiroga el panorama cambió y esta relación está marcada por su pasado como líder de los encomenderos. Quitó cualquier restricción que pudiese hacerse a este grupo en su último tiempo como gobernador y junto con Martín Ruiz de Gamboa, realizaron distintas expediciones y conquistas en tiempos que aún no llegaba Saravia a la Audiencia.

Los resultados implican que tales relaciones clientelares fueron fallidas en la gobernación de Melchor Bravo de Saravia debido a los conflictos desarrollados con los oidores, asociados a la desacreditación del poder, de los repartimientos y de los tributos. Este conflicto deterioró 
aún más el liderazgo para enfrentar la guerra. Se desconfiguraron las funciones de la Audiencia y la de sus miembros, aumentó la corrupción y se deterioraron las condiciones materiales que respaldaban al presidente y a la Audiencia en el reino. En total, el conjunto de todos estos factores amplió las críticas para definir que el tribunal no era de utilidad para Chile.

Existen dimensiones y subdimensiones en el sistema de encomiendas que explican la creación y supresión del tribunal. Todas las variables se ordenan en una cadena causal dinámica que es resultado de microfundamentos, los cuales desarrollan posteriores procesos y evolucionan en los gobiernos según las decisiones que se plantean. En suma, se ha contribuido en la utilización de metodología cualitativa actual para estudiar y clarificar eventos que marcaron el siglo XVI en Chile, específicamente para argumentar cómo los antecedentes y los intereses de los encomenderos pueden formular un grupo político importante para ir a favor de sus necesidades, similar a cómo funciona el sistema de lobby hoy en día.

La comprensión de los antecedentes y las aspiraciones de la Corona que proporcionaron una audiencia en Chile se establecen en la pugna por encomiendas realizada por las rebeliones peruanas, el Derecho Indiano y la desafiante capacidad de organización demostrada por los encomenderos. Por otro lado, la profundización de las relaciones políticas del gobernador Melchor Bravo de Saravia y de anteriores gobernadores comprueban los incentivos que existen en los encomenderos para la remoción de los líderes políticos y de la Real Audiencia de Concepción.

En total, el conjunto de variables independientes de este estudio ha logrado analizar y dar una evaluación resultante en un nuevo enfoque sobre la creación y supresión de la Real Audiencia de Concepción, sin contradecir los estudios ya realizados. Más allá de cualquier análisis sobre los resultados obtenidos, cabe resaltar que es fundamental para esta línea de investigación adentrarse en los antecedentes y origen de todas las variables para encontrar los procesos macro y socioculturales en que está envuelto este estudio.

Process Tracing ha logrado colaborar con la dirección causal del sistema de encomienda y su incidencia en la creación y supresión del tribual, puesto que ha construido una teoría amplia que incluye detalladamente distintos factores y temporalidades que apuntan a la minuciosidad de los procesos.

Para seguir esta línea de investigación, convendría complementar este trabajo considerando las gobernaciones posteriores a la Real Audiencia, lo cual puede colaborar al estudio de las relaciones clientelares entre los encomenderos y gobernadores, pero que excede las posibilidades y alcances del presente estudio. 


\section{Referencias citadas}

Academia Chilena de la Historia (AChH). 1992. Real Audiencia de Concepción 1565-1573, Santiago, Editorial Universitaria.

Angeli, Sergio. 2004. "'No a habido causa de gobierno ni justicia que yo haya contradicho': cargos y descargos del doctor Bravo de Saravia ante la visita a la Audiencia de Lima (1561-1563)" en Revista de Historia del Derecho. Sección Investigaciones, N 47, Buenos Aires, pp. 13-31

Barrientos, Javier. 1992-1993. "La Real Audiencia de Concepción (1565-1575)", en Revista de Estudios Histórico-Jurídicos, $\mathrm{N}^{\circ} 15$, Valparaíso, pp. 131-178

Barrios, Feliciano. 2004. El gobierno de un mundo. Cuenca, Ediciones de la Universidad de CastillaLa Mancha.

Barros Arana, Diego. 2000 [1884]. Historia General Tomo II, Santiago, Editorial Universitaria.

Bril-Mascarenhas, Maillet \& Mayaux. 2017. "Process tracing. Inducción, deducción e inferencia causal", en Revista de ciencia política, №3, Santiago, pp. 659-684

Cardim, Pedro y Palos, Joan. 2012. El mundo de los virreyes en las monarquías de España y Portugal, Madrid, Iberoamericana.

Castro, Daniel. 2007. Another face of empire. Bartolomé de Las Casas, indigenous rights and ecclesiastical imperialism, Durham, Duke University Press.

Clayton, Lawrence. 2012. Bartolomé de Las Casas. A biography. Cambridge, Cambridge University Press.

Contreras, Hugo. 2017a. "Indios de tierra adentro en Chile central. Las modalidades de la migración forzosa y el desarraigo (finales del siglo XVI y comienzos del XVII)" en Valenzuela, Jaime (ed.), América en diásporas. Esclavitudes y migraciones forzadas en Chile y otras regiones americanas (siglos XVI-XIX), Santiago, Instituto de Historia, Pontificia Universidad Católica de Chile, pp. 161196.

Contreras, Hugo. 2017b. Oro, tierras e indios. Encomienda de servicio personal y comunidades indígenas en Chile central, 1541-1580, Santiago, Universidad Academia Ediciones.

Contreras, Hugo. 2009. Encomienda y Servicio Personal entre las comunidades indígenas de Chile central, 1541-1580. Universidad de Chile, Tesis para optar al grado de Doctor en Historia

Cuervo, Benedicto. 2016. "La conquista y colonización de América", en Revista Historia Digital, N 28, España, pp. 103-149

Diez T, Julián. 2011. “Los marañones y la polémica de la conquista: retórica e ideas políticas en la carta de Lope de Aguirre a Felipe II", en ALPHA, №33, EEUU, pp. 201-214

Dougnac, Antonio. 2004. "Las Audiencias Indianas y su trasplante desde la metrópoli" en Feliciano Barrios (ed.), El gobierno de un mundo, Cuenca, Universidad de Castilla-La Mancha y de la Fundación Rafael del Pino, pp. 539-586. 
Drigo, Ana. 2005. La gran rebelión de Gonzalo Pizarro: liderazgo y legitimidad bajo su dirigencia en el Perú (1544-1548), Universidad de Buenos Aires, Tesis para optar al grado de Licenciatura en Ciencias Antropológicas

Errázuriz, Crescente. 1873. Los orígenes de la Iglesia chilena, 1540 - 1663, Santiago, Imprenta del Correo.

Escudero, Alfredo. 2016. El ocaso de los conquistadores: los intereses y las limitaciones materiales durante la rebelión de los encomenderos (1544 - 1548), Pontificia Universidad Católica del Perú, Tesis para optar al grado de Licenciado en Historia

Feliú, Guillermo. 1941. Las Encomiendas según Tasas y Ordenanzas, Buenos Aires, Facultad de Filosofía y Letras. Publicaciones del Instituto de Investigaciones Históricas.

García, Alfonso. 1975. "Las audiencias de Indias, su origen y caracteres" en Memoria del Segundo Congreso Venezolano de Historia, Caracas, Academia Nacional de la Historia, pp. 359-432

Garriga, Carlos. 2006. "Sobre el gobierno de la justicia en Indias (siglos XVI-XVII)", en Revista de Historia del Derecho, №34, Argentina, pp. 67-160

George, Alexander y Bennett Andrew. 2005. Case Studies and Theory Development in the Social Sciences, Cambridge, MIT Press.

George, Alexander y McKeown Timothy. 1985. "Case Studies and Theories of Organizational Decision Making" en Robert Coulam y Richard Smith (eds.), Advances in Information Processing in Organizations, Greenwich CT, JAI Press, pp. $43-68$

Goicovich, Francis. 2020. “Un reino con dos escenarios. La cuestión del trabajo y los derechos indígenas en la Gobernación de Chile en la etapa pre-jesuita: entre el nativo encomendado y el auca sublevado", en Revista Tiempo Histórico, N¹9, Santiago, pp. 17-49

Góngora, Alonso. 2016 [1575]. Historia de todas las cosas que han acaecido en el Reino de Chile y de los que lo han gobernado, Santiago, Editorial Universitaria.

Góngora, Mario. 1951. El estado en el derecho indiano, Santiago, Universidad de Chile Instituto de Investigaciones Histórico-Culturales.

Góngora, Mario. 1970. Encomenderos y estancieros, Santiago, Universitaria.

González, Javier. 1992. "Prólogo”, en Academia Chilena de la Historia (ed.), La Real Audiencia de Concepción 1565-1573, Santiago, Editorial Universitaria.

Hormaeche, Lisandro. 2010. "El sistema de la encomienda como aparato de control de la mano de obra indígena y de aculturación en el espacio Hispanoamericano (Siglos XVI y XVII)", en Cátedras Bolivarianas, Universidad Popular Madres de Plaza de Mayo, pp. 1-17

Huneeus P, Andrés. 1956. Historia de las polémicas de Indias en Chile durante el siglo XVI, 1536 1598, Santiago, Universidad de Chile.

Invernizzi, Lucía. 1989. “'¿llustres hazañas? ¿Trabajos e infortunios?' La Historia de Chile de Góngora Marmolejo", en Revista Chilena de Literatura, №33, Santiago, pp. 7-22

Levillier; Roberto. 1921. Gobernantes del Perú Cartas y Papeles, siglo XVI, Madrid, Sucesores de Rivadeneyra. 
Martiné, Eduardo. 1997. “La Audiencia de Concepción en Chile (1565 - 1573) un caso de Audiencia con expresas funciones de gobierno", en Anuario de historia del derecho español, N67, Madrid, pp. 1379-1398

Matienzo, Juan. 1967 [1567]. Gobierno del Perú, Lima, Institut Français d’Études Andines.

Mayorga, Fernando. 2013. Real Audiencia de Santafé en los siglos XVI - XVII. Historias, visitas, quejas y castigos del primer tribunal con sede en la ciudad, Bogotá, Secretaría General Alcaldía Mayor de Bogotá D.C.

Mazzei de Grazia, Leonardo. 1989. “Fundación y supresión de la audiencia de Chile: Concepción 1567-1575", en Revista de Indias, N49, Madrid, pp. 27-89

Medina, José Toribio. 1899. Colección de Documentos Inéditos Para la Historia de Chile, Tomo XIX, desde el viaje de Magallanes hasta la batalla de Maipú, 1518-1818, colectados y publicados por J.T. Medina, Valdivia y sus compañeros. 1899. Santiago, Imprenta Elzeviriana.

Medina, José Toribio. 1901. Colección de Documentos Inéditos Para la Historia de Chile, Tomo XXIX, desde el viaje de Magallanes hasta la batalla de Maipo: 1518-1818, colectados y publicados por J. T. Medina, Santiago, Imprenta Ercilla.

Medina, José Toribio. 1956. Colección de Documentos Inéditos para la Historia de Chile. Segunda Serie. Tomo I, 1558 - 1572, Rodrigo de Quiroga - M. Bravo de Saravia, Santiago, Fondo Histórico y Bibliográfico J. T. Medina.

Medina, José Toribio. 1957. Colección de Documentos Inéditos Para la Historia de Chile. Segunda Serie. Tomo II, 1573-1580. M. Bravo de Saravia - Rodrigo de Quiroga, Santiago, Fondo Histórico y Bibliográfico J. T. Medina.

Medina, José Toribio. 1959. Colección de Documentos Inéditos Para la Historia de Chile. Segunda Serie. Tomo III, 1577-1589, Martín Ruiz de Gamboa - Alonso de Sotomayor, Santiago, Fondo Histórico y Bibliográfico J. T. Medina.

Méndez, Luz María. 2019. "El jurista Fernando de Santillán, el trabajo indígena y los encomenderos en el sur de Chile, especialmente Concepción y Arauco, 1550-1559" en Clímaco Hermosilla (ed.). Historia de Arauco: Garciadas Cañetinas, conferencias escogidas 2004-2018, Cañete, Sociedad Chilena de Historia y Geografía, Agrupación Cultural Artis, pp.21- 142.

Merluzzi, Manfredi. 2010. La pacificazione del regno. Negoziazione e creazione del consenso in Perù, Roma, Viella.

Miguel y Alonso, Carlos de. 1959. "Las audiencias en los reinos y señoríos de las Indias" en Cuadernos Hispanoamericanos, n 116-117, Madrid, pp. 189-204.

Reig Satorres, José. 1972. “Las Audiencias Indianas: su origen y caracteres” en Reig Satorres, José (ed.), Reales Audiencias, Quito- Guayaquil, Anuario Histórico Jurídico Ecuatoriano, pp. 525-614.

Rivero, Manuel. 2011. La edad de oro de los virreyes. El virreinato en la monarquía hispánica durante los siglos XVI y XVII, Madrid, Akal.

Roa Palacios, Alfredo. 2015. Entre Ruinas Y Escombros: Los Terremotos en Chile Durante Los Siglos XVI al XIX. Valparaíso, Universidad de Valparaíso. 
Sagredo, Rafael. 2014. Historia mínima de Chile, Madrid y México D.F, Turner y El Colegio de México.

Salinero, Gregorio. 2015. "Rebeliones coloniales y gobierno de las Indias en la segunda mitad del siglo XVI" en Historia Mexicana, N³, Ciudad de México, pp. 895-936

Soto, Javier. 2018. Los encomenderos y las encomiendas en Concepción, 1550-1598, Universidad de Chile, Informe final del Seminario "Política, instituciones y grupos sociales (1700-1850)" para optar al grado de Licenciado en Historia

Steward, Daniel. 2019. "Historical tsunamis in the Penco Bay, as seen in the reconstructed runups from the city of Concepción, Chile (1570-1835)", en Revista de Historia de la Universidad de Concepción. $\mathrm{N}^{\circ} 27$, Concepción, pp. 97-127

Venegas, Fernando, Ávalos, Hernán y Saunier, Andrea. 2011. Arqueología e historia del curso medio e inferior del río Aconcagua. Desde los primeros alfareros hasta el arribo de los españoles (300aC-1600dC), Valparaíso, Ediciones Universitarias de Valparaíso, pp. 131-248, 187-188.

Zavala Cepeda, José Manuel., Medianero Soto, Francisco. y Zeballos San Miguel, Mirentxu. 2020. “Maquegua (Maquewe) y sus habitantes en la Araucanía del siglo XVI: geopolítica y economía aurífera en los términos de la Ciudad Imperial de Chile", en Memoria Americana. Cuadernos de Etnohistoria, N²8, pp. 117-138. 